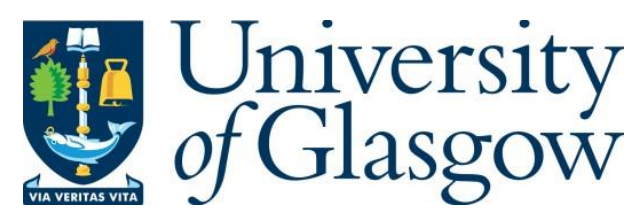

MacGregor, M. and Wilkinson, C. (2019) In search of Robert Bruce, part II: reassessing the Dunfermline tomb investigations of 1818-19. Scottish Historical Review, 98(2), pp. 159-182.

There may be differences between this version and the published version. You are advised to consult the publisher's version if you wish to cite from it.

http://eprints.gla.ac.uk/186906/

Deposited on: 20 May 2019

Enlighten - Research publications by members of the University of Glasgow http://eprints.gla.ac.uk 


\title{
In Search of Robert Bruce, Part II: Reassessing the Dunfermline Tomb Investigations of 1818-19
}

\author{
Martin MacGregor and Caroline Wilkinson
}

'Robert Bruce, the ruler of a small kingdom, is one of the big figures of history'. ${ }^{1}$ With these words the late G.W.S. Barrow began the preface to his classic Robert Bruce and the Community of the Realm of Scotland, first published in 1965. The book is the starting point for modern study of Bruce, king of Scots from 1306 until his death on 7 June 1329, and the benchmark for subsequent biographies. ${ }^{2}$ While other historians have been less consistently generous than Barrow in their estimation of Bruce as man and king, ${ }^{3}$ none would dispute his claim to greatness. In defiance of all logical probability and apparently insuperable oddssome of them self-induced-Bruce succeeded in making good his claim to the kingship by supplanting his predecessor, King John Balliol; and, as king, in restoring the liberty of the kingdom from English overlordship through the Treaty of Edinburgh in 1328. His tenacious lobbying of a hostile papacy for unqualified recognition of an independent Scottish kingship and kingdom, on a par with any other in western Christendom, bore posthumous fruit less than a week after his death, when John XXII granted to Scottish monarchs the full rite of

\footnotetext{
${ }^{1}$ G.W.S. Barrow, Robert Bruce and the Community of the Realm of Scotland (London, 1965), xix. Subsequent references are to the $3^{\mathrm{d}}$ edition (Edinburgh, 1988).

${ }^{2}$ Colm McNamee, Robert Bruce: Our Most Valiant Prince, King and Lord (Edinburgh, 2006); Michael Penman, Robert the Bruce, King of the Scots (New Haven and London, 2014).

${ }^{3}$ A. A. M. Duncan, 'The Community of the Realm and Robert Bruce', Scottish Historical Review 45 (1966) 184-201; Ranald Nicholson, Scotland: The Later Middle Ages (Edinburgh, 1974); R. J. Tanner, 'Cowing the Community? Coercion and Falsification in Robert Bruce’s Parliaments, 1309-1318', in K. M. Brown and R. J. Tanner (eds), Parliament and Politics in Scotland, 1235-1560 (Edinburgh, 2004), 50-73.
} 
crowning and anointing, a privilege which Bruce’s predecessors had sought for over a century. $^{4}$

It is interesting that the strain of scholarly equivocation towards Bruce finds its counterpart in a degree of popular distance which is there in modern Scotland: from the relatively measured reaction to the discovery of what were immediately taken to be his grave and skeletal remains at Dunfermline in 1818, to present day opinion polls inviting us to choose the greatest Scot of all. In these the blue-blooded Bruce, who died having largely fulfilled his destiny, never seems to come higher than third, with William Wallace and Robert Burns — tragic failures and meritocratic 'lads o’ pairts' who died young-invariably above him. ${ }^{5}$ Nonetheless, and returning to Barrow, Bruce’s career and achievement can be measured twice over: the ascent from the nadir of defeat and exile in 1306 to the zenith of victory over an invading English army at Bannockburn in 1314 which Barrow calls 'the story of one of the great heroic enterprises of history ... if Bruce had done nothing else he would find an enduring place in history as one of its greatest adventurers'; and the years from Bannockburn until his death in 1329 in which the adventurer became 'one of the best of medieval kings, prudent, conscientious, vigorous and patriotic' ${ }^{6}$ The Netflix feature film, ‘Outlaw King', looks set to seal and enhance his status as national and global icon.

\footnotetext{
${ }^{4}$ The Chronicle of Lanercost 1272-1346, trans. Sir Herbert Maxwell (Glasgow, 1913) [Chron. Lanercost (Maxwell)], 264; Anglo-Scottish Relations 1174-1328: some selected documents, ed. E. L. G. Stones (Oxford, 1970), xxii, 58-9, n. 1. OR ER, i, cxiii, n. 1; Calendar of Entries in the Papal Registers relating to Great Britain and Ireland: Petition to the Pope, ed. W.H. Bliss (16 vols., London, 1896), ii, 493; Vetera Monumenta Hibernorum et Scotorum Historiam Illustrantia, ed. A. Theiner (Rome, 1864), 244-5.

${ }^{5}$ M. A. Penman, 'Robert Bruce’s Bones: Reputations, Politics and Identities in Nineteenth-Century Scotland', International Review of Scottish Studies 34 (2009), 7-73, at 7-8, 51-2. For a more bullish account of the response to the discovery of 1818 see Ebenezer Henderson, The Annals of Dunfermline (Glasgow, 1879), 595. For the late-medieval origins of the debate concerning the respective merits of Bruce and Wallace see Nicola Royan, 'Scotichronicon rewritten? Hector Boece's debt to Bower in the Scotorum Historia', in B. E. Crawford (ed.), Church, Chronicle and Learning in Medieval and Early Renaissance Scotland: Essays Presented to Donald Watt on the Occasion of the Completion of the Publication of Bower's Scotichronicon (Edinburgh, 1999), 57-71, at 62-3, and n. 48.

${ }^{6}$ Barrow, Robert Bruce, 165.
} 
Does the icon have a face? Bruce's first biographer was John Barbour, the archdeacon of Aberdeen, who wrote his epic Scots poem The Bruce in the 1370s. We are fortunate to possess Barbour in the form of a splendid modern edition by the late Archie Duncan, whose own contribution to the scholarship on Robert Bruce and the First War of Scottish Independence is as immense as that of Geoffrey Barrow. ${ }^{7}$ Duncan and Barrow’s deep knowledge of the period left them both in no doubt as to the essential historicity and reliability of Barbour: in Barrow’s words, 'that he must be reckoned a biographer, not a romancer' ${ }^{8}$ Yet nowhere in Barbour's 13, 000 lines and more, or in any other contemporary or near-contemporary text, do we find any clue as to what Bruce looked like, and the images on the coinage and the two extant great seals of his reign are too derivative and formulaic to be of genuine service in this regard. ${ }^{9}$ Perhaps the closest words can bring us to the king is the first-hand testimony of the papal legates who came to Scotland in 1317 to try and persuade Bruce to abide by the will of Pope John XXII, and accept a two-year truce between Scotland and England. The legates' account of the meeting constitutes what the eighteenth-century historian Lord Hailes believed was 'the best original portrait of Robert Bruce which has been preserved to our times'. ${ }^{10}$ What is conveyed is personal charisma, mental and verbal acuity

\footnotetext{
7 John Barbour, The Bruce, ed. and trans. A. A. M. Duncan (Edinburgh, 1997).

${ }^{8}$ Barrow, Robert Bruce, 312.

${ }^{9}$ Karl Pearson, King Robert the Bruce, 1274-1329: His Skull and Portraiture (Cambridge, n.d.), 22-3 and Plate XII; [Spink], Standard Catalogue of British Coins: Coins of Scotland, Ireland and the Islands (Jersey, Guernsey, Man and Lundy): Pre-Decimal Issues (London, 2002), 21; Walter de Gray Birch, History of Scottish Seals from the eleventh to the seventeenth century. Vol. I. The Royal Seals of Scotland. (Stirling and London, 1905), 39-43, 135, 139; Regesta Regum Scottorum V: The Acts of Robert I King of Scots 1306-1329, ed. A. A. M. Duncan (Edinburgh, 1988) [RRS], 178-85. For another coin image see Birmingham Museums and Art Gallery, http://www.bmagic.org.uk/objects/1993C573; accessed 4 Feb. 2019). John Mair's History of Greater Britain, published in 1521, may provide the first verbal portrait of Robert Bruce, nearly 300 years after his death. He was 'fair to look upon, handsome of aspect, shapely and vigorous in body, broad-shouldered, of an agreeable countenance, his hair yellow, as you find it among northern nations, his eyes blue and sparkling ...' ( $A$ History of Greater Britain, as well England as Scotland ... by John Major, ed. and trans. Archibald Constable, Scottish History Society (Edinburgh, 1892), 236). My thanks to Mr Norman Robertson, Gargunnock, for drawing my attention to this reference.

${ }^{10}$ Thomas Rymer, Foedera, Conventiones, Litterae et Ciuiscunque Generis Acta Publica, 17 vols (London, 1727-9), ii. 340-1; Sir David Dalrymple, Lord Hailes, Annals of Scotland, from the accession of Malcolm III to the accession of the House of Stewart, 3 vols (Edinburgh, 1797), ii. 84.
} 
and dexterity, grace, courtesy and a ready sense of humour, alongside an uncompromising firmness and clarity of purpose concerned above all else to uphold the regia dignitas, the 'royal dignity', of the kingdom of Scotland. Yet this remains a portrait of character alone, which brings us no nearer to the outward appearance of the king.

All modern attempts to recreate the face of Robert Bruce trace their origin to 17 February 1818, when workmen engaged in building a new parish church to replace its ruined predecessor, situated within the shell of the medieval Benedictine abbey of Dunfermline, uncovered a burial vault. ${ }^{11}$ Investigations were conducted but swiftly suspended until such time as work on the new church was far enough advanced to protect the site from a curious public. ${ }^{12}$ On 5 November 1819, in this more secure setting, the vault was reopened, and the skeleton within exhumed and removed from its two protective sheets of lead. Skeleton and lead had originally been enclosed within a wooden coffin, presumed to be of oak, which by now had rotted away to form a debris layer in the bottom of the vault. The skeleton was examined; at least one cast of the skull was made in plaster of Paris; ${ }^{13}$ the public was allowed to file past and pay its respects while the skeleton lay exposed; the remains were immediately reburied where they had been found, in a reconstructed vault in a lead coffin filled with melted pitch, and an official report was published by the King’s Remembrancer, Henry Jardine. ${ }^{14}$

\footnotetext{
${ }^{11}$ [Henry Jardine], Report to the Right Hon. The Lord Chief Baron, and the Hon. The Barons of his Majesty's Court of Exchequer in Scotland, by the King's Remembrancer, relative to the Tomb of King Robert the Bruce, and the Cathedral Church of Dunfermline (Edinburgh, 1821), 28.

12 Ibid., 30-1; Henderson, Annals of Dunfermline, 602; Iain Fraser, 'The tomb of the hero king: the death and burial of Robert I, and the discoveries of 1818-19', in Richard Fawcett (ed.), Royal Dunfermline, Society of Antiquaries of Scotland (Edinburgh, 2005), 155-76, at 165-6.

${ }^{13}$ An account published in the Perthshire Courier on 18 Nov. 1819 states that 'two excellent casts' were made, while an eye witness account contained within a letter of 1 Mar. 1820 refers to the intention to take 'casts of the king's head': (['G'], 'Exhumation and Re-interment of Robert Bruce', The Quarterly Journal of Science, Literature and the Arts 9 (1820) 138-42, at 141.

${ }^{14}$ [Jardine], Report, 31-43; J. J. Coleman, Remembering the Past in Nineteenth-Century Scotland: Commemoration, Nationality and Memory (Edinburgh, 2014), 46-7. It has been suggested that 'several weeks' elapsed between exhumation and reburial (M. F. Kaufman and W. J. MacLennan, 'Robert the Bruce and Leprosy’, Henry Noble History of Dentistry Research Group Newsletter (Apr. 2001), [1]-[8], at [2]; cf. Pearson, King Robert the Bruce, 6-7). However, Jardine's report states that reinterral took place as soon as the 'immense crowd of people' gathered outside the church on 5 Nov. 1819 had been allowed to file past the exposed skeleton,
} 
Was this the burial vault and skeleton of Robert Bruce? If so, the skull cast, multiple copies of which were made after 1819, offered the tantalising prospect of restoring a face to the icon, centuries after Bruce's death. That has been the motivation behind the several attempts at facial depiction made since 1819, prominent among them the statue of Bruce by Charles Pilkington Jackson unveiled at Bannockburn in 1964. In 2016, the present authors published a new craniofacial reconstruction, based upon the skull cast held in Glasgow University’s Hunterian Museum. ${ }^{15}$ Reliance upon a cast meant the absence of the original bone and hence the unavailability of DNA, which might otherwise have provided evidence on fundamentals such as hair and eye colour, the presence or absence of disease, and ultimately_and assuming that proven living descendants of Bruce could be found to provide comparative data—-the identity of the subject.

'In Search of Robert Bruce, Part I' (hereafter referred to as Part I) explains the process behind the reconstruction, and includes contributions from specialists in genetics and medieval armoury to justify the decisions reached on hair and eye colour, and head and neck apparel and defences. It offers a fresh analysis of the skull cast to make deductions about the sex, age and physique of the individual in question, and the possible presence of disease affecting the bone. ${ }^{16}$ The present article likewise commences with the skeletal evidence, but brings to bear the medieval historical sources both to develop more fully the discussion of disease, and to add a discussion of the separate heart burial which may have been carried out upon this individual, given the sawn through sternum recorded in Jardine's report. There then

\footnotetext{
and 'the public curiosity was gratified' ([Jardine], Report, 43), implying that exhumation, examination and reburial all took place on the one day. This is also the implication of the report in the Perthshire Courier on 18 Nov. 1819. It refers to the skull being 'properly cleaned, and two excellent casts taken from it'. Jardine's reference to the presence on site of 'Mr Scoular', the artist or sculptor who 'proceeded to make a cast' ([Jardine], Report, 36), is corroborated by the eye-witness account given in the letter of 1 Mar. 1820 ([' G'], 'Exhumation and Re-interment of Robert Bruce', 142).

${ }^{15}$ See University of Glasgow, The Hunterian, https:/www.gla.ac.uk/hunterian/visit/exhibitions/virtualexhibitions/robertthebruce/; accessed 4 Feb. 2019). ${ }^{16}$ C. M. Wilkinson, Mark Roughley, R. D. Moffat, D. G. Monckton and Martin MacGregor, 'In Search of Robert Bruce, Part I: Craniofacial Analysis of the Skull excavated at Dunfermline in 1819', Journal of Archaeological Science: Reports (forthcoming).
} 
follows a summary of the third article in the series (hereafter referred to as Part III), which sets the evidence for the location of the tomb uncovered in 1818 against the available historical and architectural evidence for royal burial at Dunfermline in the medieval era. ${ }^{17}$ To these six benchmarks—sex, age, physique, disease, heart burial and tomb location —is added a seventh, namely manner of death, all of which are then combined to draw conclusions about the identity of the incumbent of the Dunfermline tomb.

Scholarly opinion on the question has fluctuated between 1818 and the present day. Initial certainty in support of Robert I gave way to scepticism before the pendulum swung back, but on a more cautious footing, in the earlier twentieth century, where it has remained until Michael Penman's recent intervention in favour of an earlier king of Scots, David I. ${ }^{18}$ In the official report, as with most other contemporary accounts, the identification with Bruce was taken as a given, and rehearsed with a zeal that brooked no contradiction. Bruce was imposed upon the evidence rather than the evidence being allowed to speak for itself, resulting in the elaboration of a series of 'proofs' based upon unreasonable conjecture, spurious science and outright falsification. Discussion of these 'proofs' can serve as a salutary and sobering point of departure for this investigation.

First is what Fraser calls 'the phantom crown'. ${ }^{19}$ To some present when the vault was first broken open on 17 February 1818, the royalism of the burial was proved by a crownshaped object above the head. According to Jardine’s report, this had been rudely formed from the same lead sheeting which covered the corpse, and he explained its absence come 5 November 1819 by its 'having probably been carried off at that time by some of the spectators'. ${ }^{20}$ A second account, carried in the Dunfermline Saturday Press and said to

\footnotetext{
${ }^{17}$ Martin MacGregor and Caroline Wilkinson, 'In Search of Robert Bruce, Part III: Medieval Royal Burial at Dunfermline and the Tomb Investigations of 1818-19' (forthcoming)

18 T. H. Bryce, 'The Skull of King Robert the Bruce', Scottish Historical Review 23 (1926) 81-91; at 81-2;

Fraser, 'The tomb of the hero king', 155, 174; Penman, Robert the Bruce, 306.

${ }^{19}$ Fraser, 'The tomb of the hero king', 169.

20 [Jardine], Report, 30, 35.
} 
derive from an eye-witness present on 17 February 1818, speaks instead of a 'cloth of gold which had been plaited round his head so as to resemble a crown' ${ }^{21}$ Presumably this was part of, or related to, the embroidered cloth, 'evidently of fine linen, interwoven with threads of gold', which in Jardine’s opinion 'had apparently been thrown loosely over the lead as a shroud, after the body had been deposited in the coffin'. Already decayed when first exposed in 1818, by 5 November 1819 the cloth was reduced to fragments, some of which were preserved by Jardine and others; specimens survive in Scottish museums, still awaiting an investigation more thoroughgoing than that undertaken by Jardine in $1819 .{ }^{22} \mathrm{~A}$ third, eyewitness account of the elusive crown offers a composite of the other two, while favouring the disintegration of the cloth to explain its vanishing act on 17 February 1818:

something of the appearance of a crown ... possibly a part of the shroud, folded in that form round somewhat similar folds in the lead, and [which] must have instantly disappeared on exposure to the air, since others, on having their attention drawn to it, could not observe it. ${ }^{23}$

\footnotetext{
${ }^{21}$ See the newspaper cutting pasted into the blank opening pages of the copy of Jardine's report held by The Library of the University of California, Los Angeles, and available online at https://archive.org/details/reporttorighthon00scot; accessed 4 Feb. 2019. This account describes the coffin in which the body had originally lain as made of oak.

${ }^{22}$ [Jardine], Report, 30, 38-9; Fraser, 'The tomb of the hero king', 168. For the specimen held by the Hunterian Museum see https://www.gla.ac.uk/hunterian/visit/exhibitions/virtualexhibitions/robertthebruce/; accessed 4 Feb. 2019. Rather than directly overlying the lead sheeting within the coffin, as Jardine implies, perhaps the cloth was originally draped over the coffin—as indicated for Alexander III king of Scots (d. 1286) in an illustration of his funeral in a manuscript of Walter Bower's mid-fifteenth-century Scotichronicon-and only came to be in direct contact with the lead once the coffin wood rotted away; Scotichronicon by Walter Bower in Latin and English, gen. ed. D. E. R. Watt, 9 vols (Aberdeen, 1987-98) [Watt, Scotichronicon], v. 289 (facing page), 513. However, the Perthshire Courier's report of 18 Nov. 1819 is supportive of Jardine: 'A point, on which much diversity of opinion had been entertained since the first opening of the grave, was now settled, that the shroud was above not under the lead; sanctioning the supposition that the body may have lain in state previous to interment, when this rich covering, consisting of fine damask cloth, interwoven with gold, would be exhibited; as also, that it had been enclosed in a wooden coffin, when laid in the tomb, of which some vestiges, as formerly notices, remained'.

${ }^{23}$ Peter Chalmers, Historical and Statistical Account of Dunfermline (Edinburgh and London, 1844), 139-40;

Fraser, 'The tomb of the hero king', 167-8.
} 
Another token of royalism mentioned in Jardine's report is:

a small head, cut in soft stone, which appears to have been intended to represent the head of the King. The face is unfortunately destroyed, but the crown on the head, and the hair under it, are precisely of the form and style represented in [Bruce's] coins. ${ }^{24}$

Jardine includes this in his concluding discussion of surviving fragments of the marble box tomb which Bruce is known to have commissioned before his death, and which would have surmounted his burial vault in Dunfermline Abbey, but which has not survived. Since Jardine's wording makes no explicit linkage between this head and the investigations of 1818-19, it might have been recovered at another time, and from another location within the abbey. It has since been identified as one of a number of surviving fragments, not of marble but siltstone, and from a tomb of a date much later than Bruce’s. ${ }^{25}$

According to Jardine, the skull exhibited:

a considerable fracture of the jaw-bone in front, evidently occasioned by a blow, which the King is supposed to have received in one of those many extraordinary adventures to which he was exposed in the early part of his life. ${ }^{26}$

The report's first appendix by the surgeon Robert Liston is devoted to a description of the skull, and refers to 'a kind of mark on the right side of the sagittal suture, most probably the consequence of a severe injury’. ${ }^{27}$ To both commentators the skull of a warrior-king like

\footnotetext{
24 [Jardine], Report, 46.

${ }^{25}$ Pearson, King Robert the Bruce, 4 and Plate VIII; Fraser, 'The tomb of the hero king', 157, 172.

${ }^{26}$ [Jardine], Report, 36.

${ }^{27}$ Ibid., 51-2. For apparent inconsistency in Liston's use of left and right in his appendix, see Wilkinson et al., 'In Search of Robert Bruce, Part I'.
} 
Robert Bruce could not but bear witness to a violent life, just as his skeleton could only be that of a man of stature, 'about 5 feet 11 inches to 6 feet', in contrast to more recent estimates of between five feet six and a half and five feet nine and a half inches. ${ }^{28}$ This appendix was followed by a significantly longer one in which the contemporary pseudo-scientific cult of phrenology was invoked to read the skull as an index of Bruce's temperament and character: 'we find, that while it indicates but middling talent, it exhibits all the qualities of the Leader and Warrior'. ${ }^{29}$ One of those who provided commentary was no less than George Combe, the Scots-born presiding guru of the phrenological movement. ${ }^{30}$

Another elusive proof was the potential presence nearby of Bruce’s queen Elizabeth, daughter of Richard de Burgh the earl of Ulster. Jardine notes that in February 1818 he saw part of a burial vault which had been discovered some years previously, lying only a few feet from that believed to be Bruce’s, and:

very similar in its construction ... but of smaller dimensions ... In this, I was told the remains of a human skeleton were found; and it has even been asserted, that it was ascertained to be that of a female. From the situation of this vault ... I am inclined to think it contained the remains of King Robert's Queen, who, as Fordun says, was placed juxta sponsum suum [beside her husband]; but the skeleton was removed from the place before I had an opportunity of seeing it.-A plan and section of it is delineated in plate No. $2 .^{31}$

\footnotetext{
28 [Jardine], Report, 37; Pearson, King Robert the Bruce, 6-7; Fraser, 'The tomb of the hero king', 168. ${ }^{29}$ [Jardine], Report, 53-60.

${ }^{30}$ L. S. Jacyna, 'Combe [Comb], George (1788-1858)', Oxford Dictionary of National Biography (Oxford, 2004) [http://www.oxforddnb.com/view/article/*****; accessed 21 Jan. 2019] ; Colin Kidd, 'Sentiment, race and revival: Scottish identities in the aftermath of Enlightenment', in L. W. B. Brockliss and David Eastwood (eds), A Union of multiple identities: The British Isles, c. 1750-c. 1850 (Manchester, 1997), 110-26, at 117. 31 [Jardine], Report, 47. This 'plan and section' seem to be missing from the published report, Plate 2 of which (according to the 'Note' which ends the accompanying 'Explanation') depicts the skeleton investigated on 5 Nov. 1819.
} 
Finally and most flagrantly, a copper plate bearing the inscription Robertus Scotorum Rex, 'Robert King of Scots', was discovered among the tomb debris - but not until 10 November, five days after the official investigation had started and ended. This met the need, left unsatisfied by the investigation, for an inscription to go with the grave, and was heralded by Jardine's report as putting the matter of identification 'beyond the possibility of doubt', only to be confirmed decades later as a forgery, the outcome of a premeditated hoax. ${ }^{32}$

Commencing a reappraisal of the evidence with the cast of the skull of the skeleton exhumed in 1819, its size and robustness confirm firstly and secondly that this was a male whose physique was muscular, thick-set and exceptionally powerful in neck and torso. ${ }^{33}$ Third, the condition of the teeth suggests that at the time of death the subject was neither a young nor a very old adult but of middle age, within an approximate range of 40 to 65 years. ${ }^{34}$ Fourth, Jardine's report noted that, 'the whole teeth in the under jaw were entire and in their places, but there were four or five in the upper jaw wanting, with a considerable fracture of the jaw-bone in front'. ${ }^{35}$ The corresponding passage in the appendix by Robert Liston states:

The four incisors of the upper jaw are wanting; and the loss of the left central, and two right ones, seems to have been attended with considerable fracture of the sockets. The left lateral one appears to have dropped out at a later period, as part of the alveoloer process is unabsorbed. ${ }^{36}$

\footnotetext{
32 [Jardine], Report, 44-5; Henderson, Annals of Dunfermline, 605-6; Pearson, King Robert the Bruce, 5-6 and Plate VII; Fraser, 'The tomb of the hero king', 168-9; Penman, 'Robert Bruce’s Bones', 35-6.

${ }^{33}$ [Jardine], Report, 51-2; Pearson, King Robert the Bruce, 16; Bryce, 'The Skull of King Robert the Bruce’, 90; Wilkinson et al., 'In Search of Robert Bruce, Part I'.

${ }^{34}$ Ibid.; Iain MacLeod and Brian Hill, Heads and Tales: Reconstructing Faces, National Museums of Scotland (Edinburgh, 2001), 39.

35 [Jardine], Report, 36.

${ }^{36}$ Ibid., 52. A letter of 1 March 1820 said to have been written by James Gregory, Professor of Medicine at the University of Edinburgh, who took an active part in proceedings at Dunfermline on 5 Nov. 1819, claims that the skull's teeth 'were very entire' at the point of exhumation, and only came out at the stage of making a cast (['G'], 'Exhumation and Re-interment of Robert Bruce', 141). The account in the Perthshire Courier of 18 Nov.
} 
Jardine had already noted that Bruce had died of 'a tedious illness, ascribed to the leprosy', but drew no connection between this and the damage to facial bone which for him as for Liston could only be trauma injuries, testimony to the valour of a warrior-king. ${ }^{37}$ A century later, Pearson initially took the same line — 'the upper incisors and a portion of the upper jaw have been broken away possibly by a blow from battle-axe or spear’—but went on to admit: 'it is even possible that the peculiarities of the teeth and of the defective upper jaw might have to be viewed from a standpoint other than that of war-time injury' ${ }^{38}$ Part I maintains that the skull-cast exhibits, firstly, no convincing evidence of healed trauma, and secondly, a pattern of bone deterioration and loss affecting the upper incisors, related alveolar (socket) bone, and nasal bones, consistent with a diagnosis of leprosy. However, it also acknowledges the possibility that this 'pattern' may be post-mortem, and a consequence of the handling of the remains. A firm conclusion cannot be drawn on this point without access to the original skull. ${ }^{39}$

For at least the last two years of his life, Robert Bruce suffered from a medical condition which seems to have fluctuated in its severity, but at its worst left him at points points reliant on others to carry him, presumably by litter, and at others scarcely able to 'move anything but his tongue'. ${ }^{40}$ Contemporary or near-contemporary non-Scottish chroniclers, writing in Latin and French, refer to the king and his condition as follows:

\footnotetext{
1819 agrees with Jardine's official report and contradicts Gregory in stating that at the point of exhumation and before the casts were made, 'the teeth on the under jaw were all remaining, but a few on the upper were wanting'.

${ }^{37}$ [Jardine], Report, 19.

${ }^{38}$ Pearson, King Robert the Bruce, 16-17.

${ }^{39}$ Wilkinson et al., 'In Search of Robert Bruce, Part I'.

${ }^{40}$ Ranald Nicholson, 'A Sequel to Edward Bruce’s Invasion of Ireland', Scottish Historical Review 42 (1963) 30-40, at 34; Barrow, Robert Bruce, 319, 323; Penman, Robert the Bruce, 297-9.
} 
leprosus; ${ }^{41}$ lepra percussus; ${ }^{42}$ le Roy Robert, qui mort estoit de lepre $;{ }^{43}$ la grosse maladie. ${ }^{44}$

These terms, especially Latin lepra, were used in medieval sources of a disease which was

then widespread in Europe, before declining in the later middle ages. ${ }^{45}$ In Scotland, it was

found on the mainland into the seventeenth century, and later still in Shetland as in other

parts of far northern Europe. ${ }^{46}$

It cannot be assumed that the lepra of the middle ages was synonymous with the

condition now generally known in English to a lay audience as leprosy, and to clinicians

since 1873 as Hansen's disease. ${ }^{47}$ An important distinction is that definitions of medieval

lepra 'were sufficiently elastic to embrace at least some venereal infections' ${ }^{48}$ Both points

may be relevant to the present discussion since Robert Bruce, who was married twice, is

known to have had at least five sons and daughters with other women, while Pearson

suggested that the Dunfermline skull cast might exhibit evidence for the pitted bone surface

\footnotetext{
${ }^{41}$ Chronicon de Lanercost M.CC.I-M.CCC.XLVI, ed. Joseph Stevenson, Bannatyne Club (Edinburgh, 1839) [Chron. Lanercost], 264.

${ }^{42}$ Chronicon Domini Walteri de Hemingburgh, ed. H. C. Hamilton, 2 vols [Chron. Hemingburgh] (London, 1848-9), ii. 301. For the manuscripts upon which the 'Edward III' section of Hamilton's edition of the Chronicle of Walter of Hemingburgh is based, see Chron. Hemingburgh, ii. vii. For the relationship of these manuscripts to the Chronicle of Walter of Guisborough as edited by Rothwell, see The Chronicle of Walter of Guisborough, previously edited as the chronicle of Walter of Hemingford or Hemingburgh, ed. Harry Rothwell, Royal Historical Society (London,1957), xiii. Rothwell comments further (xxiii-iv): 'the 1327-46 portion of the chronicle as previously edited adheres to the rest of the chronicle only by the most tenuous of threads and I have in fact rejected it as a part of the chronicle'. He calls it (xxiv) a 'nameless chronicle of the years 1327-46 ... related in some way to the manuscripts of the unpublished Historia Aurea'. The Historia Aurea by John of Tynemouth ends in 1347. See further V. H. Galbraith, 'Extracts from the Historia Aurea and a French "Brut" (1317-47)’, English Historical Review 43 (1928) 203-17.

${ }^{43}$ Sir Thomas Gray, Scalacronica, 1272-1363, ed. Andy King, Surtees Society (Woodbridge, 2005) [King, Scalacronica], 106-7.

${ }^{44}$ Les Vrayes Chroniques de Messire Jehan le Bel, ed. M. A. Polain, 2 vols (Brussels, 1863), i. 33, 48, 79.

${ }^{45}$ Luke Demaitre, Leprosy in Premodern Medicine: A Malady of the Whole Body (Baltimore, 2007), 82, 85-8; Carol Rawcliffe, Leprosy in Medieval England (Woodbridge, 2006), 346, 348-9.

46 J. Y. Simpson, 'Antiquarian Notices of Leprosy and Leper Hospitals in Scotland and England Parts I-III', The Edinburgh Medical and Surgical Journal 149 (1841) 1-30; 150 (1842) 1-36; 151 (1842) 1-37; P. H. Brown, Scotland before 1700: from contemporary documents (Edinburgh, 1893), **; R. M. Clay, The Mediaeval Hospitals of England (London, 1909), **; M. W. Stearns, 'Robert Henryson and the leper Cresseid', Modern Language Notes 59 (1944) 265-269; John Durkan, 'Care of the Poor: Pre-Reformation Hospitals', in David MacRoberts (ed.), Essays on the Scottish Reformation, 1513-1625 (Glasgow, 1962), 116-28, at ***; Peter McNeill and Ranald Nicholson (eds) An Historical Atlas of Scotland, c.400-c.1600, Atlas Committee of the Conference of Scottish Medievalists (St Andrews, 1975), ***; I. B. Cowan, I.B., and D. E. Easson, Medieval Religious Houses: Scotland (London, 1976), ***; Peter Richards, The Medieval Leper and his northern heirs (Cambridge, 1977).

${ }^{47}$ Rawcliffe, Leprosy in Medieval England, 11-12; Demaitre, Leprosy in Premodern Medicine, vii-viii.

${ }^{48}$ Rawcliffe, Leprosy in Medieval England, 88-9.
} 
associated with syphilis. ${ }^{49}$ Bryce and other authorities have subsequently disagreed with this interpretation, and it is likewise rejected in Part I, but all agree that a diagnosis of leprosy can neither be absolutely confirmed nor denied without direct skeletal assessment. ${ }^{50}$

Caveats granted, recent DNA research has suggested that the bacterium responsible for medieval lepra evolved extremely slowly, and is in fact very closely related to the bacterium responsible for modern leprosy. ${ }^{51}$ Medieval medical texts commented extensively on lepra, and their analysis of its symptoms and progression holds much in common with the descriptions and depictions of the leprosy of later centuries. ${ }^{52}$ One of the most influential of the medieval texts, Bernard de Gordon's Lilium medicine, dates to Bruce’s lifetime. ${ }^{53}$ In his final years Bruce is known to have been attended by leading medical practitioners both from Gaeldom and the continent: his own Gaelic court physicians were supplemented by the Milanese Maino de Maineri, seconded from his teaching post at the University of Paris. ${ }^{54}$ Bruce was also attended by apothecaries, but insufficient evidence survives to determine what treatments they may have prescribed for him, and what ailment these might imply. ${ }^{55}$ Nonetheless, had Bruce suffered from lepra, there can be little doubt that his doctors would have been capable of diagnosing it, given their calibre and the state of contemporary medical understanding of the disease.

\footnotetext{
${ }^{49}$ A. H. Dunbar, Scottish Kings: A Revised Chronology of Scottish History 1005-1625 (Edinburgh, 1906), 1412; Rawcliffe, Leprosy in Medieval England, 89; Pearson, King Robert the Bruce, 2, 17-18; Penman, Robert the Bruce, 304.

${ }^{50}$ Bryce, 'The Skull of King Robert the Bruce', 90-1; V. Moller-Christensen and R. G. Inkster, 'Cases of leprosy and syphilis in the osteological collection of the Department of Anatomy, University of Edinburgh, with a note on the skull of King Robert the Bruce', Danish Medical Bulletin 12 (1965) 11-18, at **.

${ }^{51}$ Ann Gibbons, 'On the Trail of Ancient Killers', Science 340 (2013) 1278-1282.

52 Simpson, 'Antiquarian Notices of Leprosy, Part II’; Richards, The Medieval Leper, 98-120; Demaitre, Leprosy in Premodern Medicine, 196-239.

53 Demaitre, Leprosy in Premodern Medicine, 17.

${ }^{54}$ Caroline Proctor, 'Physician to The Bruce: Maino De Maineri in Scotland', Scottish Historical Review 86 (2007) 16-26.

55 The Exchequer Rolls of Scotland, eds. J. Stuart et al., 23 vols, H. M. General Register House (Edinburgh, 1878-1908) [ER], i. cxxi-ii, 176, 213.
} 
Two questions follow. Would the non-Scottish chroniclers have had access to informed and accurate information about Bruce's condition? The possibility should be allowed, for the Chronicle of Lanercost, Thomas Gray's Scalacronica and Jean le Bel's Vrayes Chroniques are all well-versed in Scottish affairs, with access to written and perhaps also oral Scottish sources now lost. ${ }^{56}$ Secondly, would they have reported their information in good faith? It has been asserted that since these chronicles were composed either by English clergy in the case of Lanercost, or by laymen who fought against the Scots—-the Englishman Thomas Gray and the Hainault Jean le Bel—it was in their interests to make Bruce die of a disease that carried a stigma. ${ }^{57}$ This is not a charge that stands up well to closer scrutiny. Northern English chronicles like Lanercost had special reason to be hostile to the Scots under Bruce, who bled the region dry through punitive raiding from 1311 onwards. ${ }^{58}$ However, while the raids were destructive, they were highly disciplined and not indiscriminate, as Lanercost was willing to recognise. ${ }^{59}$ It shared in the intriguing, ambivalent stance which northern English communities and chroniclers developed towards Bruce: deploring what he visited upon them even as they acknowledged that here was a king who was protecting his people in a way in which their own king, Edward II, manifestly was not, and who would treat them as they treated him. ${ }^{60}$ Lanercost speaks of Bruce as king of Scotland as early as 1312, and says that after his famous victory at Bannockburn in 1314, he 'was commonly called King of Scotland by all men, because he had acquired Scotland by force of arms' ${ }^{61}$ Later, it says of Bruce, 'I would not call him king, but usurper', only to proceed to break its own injunction. ${ }^{62}$ Thomas Gray and Jean le Bel, soldiers both, respond positively to Bruce and the

\footnotetext{
${ }^{56}$ Barrow, Robert Bruce, 323; King, Scalacronica, xlv-li.

${ }^{57}$ Penman, Robert the Bruce, 302.

58 See the later Chronica Monasterii de Melsa, ed, E. A. Bond, 3 vols (London, 1866-8), ii. 275-358.

${ }^{59}$ Chron. Lanercost (Maxwell), 194-5, 200, 205, 213, 219-21.

${ }^{60}$ Ibid., 177-258.

${ }^{61}$ Ibid., 197, 210.

62 Ibid., 239, 242.
} 
Scots as worthy and capable adversaries. Gray’s latest editor concludes that he ‘was not generally given to elaborating on his sources, or to vilifying the Scots in general, or Bruce in particular’ ${ }^{63}$ Le Bel refers several times to Bruce as proeu or valorous, and his account of Bruce on his deathbed depicts him in the best of Christian and chivalric lights, concluding: 'And after that the valorous king of Scotland passed from this earthly world' ${ }^{64}$ To explain these chroniclers' references to Bruce's lepra as a propagandist smear is to misrepresent the quality of the information available to them, and their attitude towards him.

A separate argument advanced against lepra as Bruce’s ailment is that, as Barrow notes, the historical evidence suggests no obvious effort to isolate him from others at the end of his life, even if possible hints in this direction exist in the case of his queen and son. ${ }^{65}$ Belief in the need for segregation to combat lepra was less pronounced in the earlier middle ages, but had gained ground by Bruce's time, as medical and then popular thinking came to regard the disease as potentially contracted through contact or close proximity. Yet this never eclipsed the belief in other causal factors, and in England, 'not all lepers were shunned, feared or required to depart for solitary places'. ${ }^{66}$ Rawcliffe draws attention to a notable English contemporary of Bruce’s, Richard Wallingford, abbot of St Albans from 1327 until his death in 1336. In these years Wallingford contracted lepra and died of it, but his fellow brethren stood by him in the face of external attack: 'he meets with us daily, and as his works make manifest, he has borne himself with honour from the time he undertook his office, and he continues to do so, in matters both spiritual and temporal' ${ }^{67}$ As he failed in his final years, Wallingford's administrative burden was eased by the appointment of a coadjutor or deputy,

\footnotetext{
${ }^{63}$ King, Scalacronica, xlv.

${ }^{64}$ Polain, Les Vrayes Chroniques, i. 33, 47-8, 79-81.

${ }^{65}$ Barrow, Robert Bruce, 323, 380-1; Kaufman and MacLennan, 'Robert the Bruce and Leprosy', [7]-[8].

${ }^{66}$ Rawcliffe, Leprosy in Medieval England, 4, 90-5, 253, 354.

${ }^{67}$ Ibid., 200-1, 253-4; Richard of Wallingford: an edition of his writings with introduction, English translation and commentary, ed. J. D. North, 3 vols (Oxford, 1976), i. 546-7, ii. 4-13.
} 
a role performed for Bruce by his most trusted lieutenants, Sir Thomas Randolph and Sir James Douglas.

The Scottish chroniclers writing nearest to Bruce's time do not speak of lepra or its vernacular counterparts. Barbour does not give a name to Bruce’s final illness. He says that it had its origins in his 'fundying' or 'enfundey(i)ng'—meaning a severe chill—brought on in turn by his 'cald [cold] lying' when he was in his 'gret myscheiff', or great tribulations. ${ }^{68}$ This must refer to the consequences of the exposure to the elements Bruce had to endure, as a fugitive and on campaign, from 1306 to 1309. It is known that he was laid low at Christmas 1307. At that time, according to Barbour, with contemporary sources offering a degree of confirmation, Bruce ceased to eat and drink and, unable to ride or walk, had to be transported by litter, drained of all strength and near to death, only returning to health come May $1308 .{ }^{69}$ The chronicler Andrew of Wyntoun's 'lang seknes’ may echo Barbour. ${ }^{70}$ The other principal Scottish chroniclers and historians from John of Fordun in the later fourteenth century to John Mair in the early sixteenth century make no mention of Bruce's final illness and cause of death. Interestingly, the two other main sixteenth-century Scottish historians, Hector Boece and George Buchanan, align themselves with the non-Scottish chroniclers rather than Barbour, stating that Bruce, already weakened by age and tribulation, succumbed to lepra or elephantia — the preferred Renaissance term for leprosy—which he contracted shortly before his death. ${ }^{71}$

\footnotetext{
${ }^{68}$ The Bruce, ed. and trans. Duncan, 744-7; Susan Rennie and W. A. Craigie, Dictionary of the Scots Language: Dictionar o the Scots Leid, s.v. 'fundying', 'enfundey(i)ng' [http://www.dsl.ac.uk/; accessed 4 Feb. 2019).

${ }^{69}$ The Bruce, ed. and trans. Duncan, 318-31; cf. Johannis de Fordun Chronica Gentis Scotorum, ed. W. F. Skene (Edinburgh, 1871) [Chron. Fordun], 343-4.

${ }^{70}$ The Orygynale Cronykil of Scotland by Androw of Wyntoun, ed. David Laing, 3 vols (Edinburgh, 1872-9), ii. 375.

${ }^{71}$ Hector Boethius, Scotorum Historia (1575 version), ed. and trans. D. F. Sutton (The University of California, Irvine, 2010), Book XIV, ch. 56 [http://www.philological.bham.ac.uk/boece/; accessed 4 Feb. 2019]; George Buchanan, Rerum Scoticarum Historia (1582), ed. and trans. D. F. Sutton (The University of California, Irvine, 2003 rev. 2009), Book VIII, ch. 48 [http://www.philological.bham.ac.uk/scothist/; accessed 4 Feb. 2019); Demaitre, Leprosy in Premodern Medicine, 88-91.
} 
Whom then do we believe: Barbour or the non-Scottish chroniclers? In Barbour's favour, Bruce's two bouts of illness do seem to have exercised a similar prostrating and virtually paralysing effect upon him on each occasion, which might suggest the same condition. Yet the bouts were twenty years apart, and in the later instance the pattern looks different, phases of acute infirmity apparently alternating with phases of remission. If one condition were responsible then it is unlikely to have been leprosy, even allowing for the diversity of its symptoms, and the long and unpredictable path the disease can sometimes follow. Leprosy may indeed 'take the best part of a decade or even longer to develop', 'can enter long periods of remission', and can cause 'a strange lameness ... in ... limbs and joints, which resembles that after a stroke'; ${ }^{72}$ but its basic profile of gradual if potentially erratic escalation over time does not readily square with two phases of acute illness, apparently separated by twenty years of reasonable health. However, the primary subject matter of Barbour's poem is the chivalry and heroism epitomised by Robert Bruce. It can be argued that Barbour's need to elevate Bruce was greater than was the non-Scottish chroniclers’ need to denigrate him, and that it makes for poor logic to favour his testimony on Bruce's illness over theirs on propagandist grounds. While Barrow fairly observes that Barbour makes no attempt to disguise the debilitating impact of Bruce's final illness upon him, had Barbour believed that lepra were responsible it would have been understandable were he to have sidestepped the fact and distanced the king from a feared, potentially crippling and disfiguring malaise. ${ }^{73}$

The main conclusion drawn from this review is that no substantive grounds exist for disregarding the witness of those sources which advance lepra as the primary cause of Robert Bruce's death. An obvious means of bringing some reconciliation to the evidence would be to

\footnotetext{
${ }^{72}$ Rawcliffe, Leprosy in Medieval England, 2; Demaitre, Leprosy in Premodern Medicine, 218; Richards, The Medieval Leper, 102.

${ }^{73}$ Barrow, Robert Bruce, 323.
} 
propose that he suffered from two separate ailments: that which afflicted him in 1307/8, followed twenty years later either by lepra alone, or by lepra alongside a recurrence of the earlier ailment. Bruce’s earlier ill health may have given Barbour a means of explaining his final and fatal illness; he may have been acting partly in good faith, but he may also have been economical with the truth.

Fifth, Jardine’s report noted that the corpse’s breastbone or sternum 'had been sawed asunder longitudinally from top to bottom'. ${ }^{74}$ This was for him 'the most satisfactory evidence that it was the body of King Robert Bruce', ${ }^{75}$ since it married so well with one of the most famous, and securely documented, episodes in the Bruce canon: the removal of his heart after death and before burial, to be carried by Sir James Douglas 'to the Holy Land and to the help of Christians against the Saracens', thereby enabling Bruce to fulfil in death what he had been unable to fulfil in life, and take part in a crusade. ${ }^{76}$ In the case of leprosy both propositions germane to the proof - that the skull cast manifests leprosy, and that Bruce had leprosy_are disputed. In the present case, by contrast, both propositions — that the Dunfermline skeleton's sternum was split, and that Bruce's heart was removed from his body prior to burial—are accepted. Jardine may have spoken prematurely nonetheless, for 'the extraction of the inner organs and the separate burial of the heart and intestines was a hallmark of English and French aristocratic mortuary behaviour from the 12th century onwards', ${ }^{77}$ and 'fairly frequent among the royalty and aristocracy of western Europe' by the thirteenth century. ${ }^{78}$ However, Scottish instances are not attested before the later thirteenth century, and the earliest evidence for its occurrence within the royal dynasty is for Alexander

\footnotetext{
74 [Jardine], Report, 28, 30, 37.

${ }^{75}$ Ibid., 37.

${ }^{76}$ The Bruce, ed. and trans. Duncan, 750-73; G. G. Simpson, 'The Heart of King Robert I: Pious Crusade or Marketing Gambit?’, in Crawford (ed.), Church, Chronicle and Learning, 173-86.

${ }^{77}$ Estella Weiss-Krejci, 'Heart burial in medieval and early post-medieval Central Europe', in Katharina RebaySalisbury, M. L. S. Sorensen and Jessica Hughes (eds), Body Parts and Bodies Whole: Changing Relations and Meanings. Studies in Funerary Archaeology, 5 (Oxford, 2010), 119-134, at 120; Danielle Westerhof, Death and the Noble Body in Medieval England (Woodbridge, 2008), 141-9.

${ }^{78}$ Simpson, 'The Heart of King Robert I', 174.
} 
III. ${ }^{79}$ While lack of evidence cannot preclude the possibility that the practice was already operative in Scotland in the time of David I (d. 1153) and Malcolm IV (d. 1164), and applied to them, this would be markedly earlier than the earliest known instances in either the English or French royal dynasties, in 1199 and 1252 respectively. ${ }^{80}$

Sixth, for Jardine the burial vault's location was as decisive as the split sternum in proving that it belonged to Robert Bruce. In his Scotichronicon, compiled in the 1440s, Walter Bower records that Bruce was buried at Dunfermline in 1329 in medio chori, cum debito honore, 'in the middle of the choir, with due honour'. ${ }^{81}$ From his later vantage point he is also able to record the burial of Bruce's queen Elizabeth de Burgh in 1327 in choro de Dunf' juxta regem Robertum sponsum suum, 'in the choir of Dunfermline, beside King Robert her husband'. ${ }^{82}$ Barbour also places Bruce’s burial in the choir at Dunfermline, 'in a fayr tumb' ${ }^{83}$ According to Jardine the burial vault uncovered on 17 February 1818 was 'in a line with the very centre of the ancient cathedral', and the 'Plan of the Old and New Church' produced for Jardine’s report by William Burn, who was responsible for the building of the new parish church, shows the vault on this medial line, in what according to the plan would have been the choir of the abbey in $1329 .{ }^{84}$ This must indeed be so, for although the choir is lost, its bounds are determined by structures that do survive, and date to1250 or before: to the west, the splendid Romanesque building which would have acted as the nave to this choir; to the east, the remnants of the shrine and chapel to which the remains of Queen Margaret (d.

\footnotetext{
${ }^{79}$ Watt, Scotichronicon, v. 420-1. For an argument that Alexander II underwent heart burial on his death in 1249, see L. H. S. Dean, 'Crowns, Wedding Rings, and Processions: Continuity and Change in the Representations of Scottish Royal Authority in State Ceremony, c. 1214 - c. 1603', unpublished Ph.D. thesis (University of Stirling, 2013), 31-3. For reservations concerning the evidence for Alexander III see Simpson, 'The Heart of King Robert I', 183-4, n. 23. Elizabeth de Burgh underwent separate entrail burial at Cullen, where she died: ER i. cxxv.

${ }^{80}$ Simpson, 'The Heart of King Robert I', 174-5.

${ }^{81}$ Watt, Scotichronicon, vii. 44-5.

${ }^{82}$ Ibid., vii. 34-5.

83 The Bruce, ed. and trans. Duncan, 756-7.

${ }^{84}$ [Jardine], Report, 28 and facing page.
} 
1093) were translated in $1250 .{ }^{85}$ The match of documentary and physical evidence, strengthened by the earlier discovery 'a few feet' from this vault of another vault which Jardine believed might have been Elizabeth de Burgh’s, ${ }^{86}$ explains the conclusion drawn immediately in 1818, and upheld by the official report, that this was Bruce's tomb.

The unshakeable confidence of that conclusion must be questioned on two counts. Firstly, other royal burials, male and female, took place at Dunfermline’s medieval church, a fact which the report initially acknowledged but thereafter ignored. Secondly, the task of locating these burials, both absolutely and relative to one another, is severely compromised by the loss of so much of what was the eastern arm of Dunfermline Abbey once it assumed its full form, including the choir. Investigation of what does physically survive has been limited, the most significant archaeological excavation to have a bearing on burial remaining that undertaken by Peter Macgregor Chalmers in 1916. To date, therefore, understanding of issues essential to establishment of the location of medieval royal burials at Dunfermline- the successive stages involved in the building of the church, their chronology, and the changing internal topography of the church, especially the location of the high altar-has been forced to rely heavily upon intelligent conjecture. The consensus divides these burials into three groups. The first consisted of Queen Margaret (d. 1093), her husband Malcolm III, and their sons Edward, Edgar and Alexander I (d. 1124), all buried in the vicinity of the high altar of the church Margaret built at Dunfermline. The second, further east, consisted of Margaret and Malcolm's son David I (d. 1153), and his grandson Malcolm IV (d. 1164), buried before the high altar of the choir which David added to Dunfermline when he replaced his mother's church and raised it to abbatial status; to whom were later added (here the consensus weakens) Alexander III (d. 1286) and Robert I (d. 1329). The presence in this category of

\footnotetext{
${ }^{85}$ Watt, Scotichronicon, v. 296-9.

86 [Jardine], Report, 47.
} 
David I and Robert I would also imply the presence of Elizabeth de Burgh, and of Margaret Plantagenet, first wife of Alexander III, who is said in Gesta Annalia I and the Scotichronicon to have been buried juxta regem David, 'beside King David', on her death in 1275. ${ }^{87}$ Less attention has been paid to the third group, of royal and quasi-royal burials made between 1329 and 1420, but Part III concludes that all these probably took place at locations other than the choir, principally the Lady Chapel added to the north side of the abbey at some point in the fourteenth century. ${ }^{88}$

The most substantial discussions of the second group are by Thomas Bryce in 1926 and Iain Fraser in 2005. ${ }^{89}$ Bryce built upon Francis Eeles’s hypothesis that when Queen Margaret (d. 1093) was canonised in 1250 and her tomb transferred to the feretory chapel which was added to the eastern end of Dunfermline Abbey, the choir itself was extended and the high altar of David I's abbey moved 'a bay farther east' ${ }^{90}$ On the basis of William Burn's plan, Bryce deduced that the location of the burial vault of 1818-19 'must have coincided very nearly’ with the site of the high altar of David I’s abbey. ${ }^{91}$ Hence this vault must represent a post-1250 royal burial, and confirmation of Eeles’s hypothesis. Bryce therefore envisaged David I and Malcolm IV as buried before the site of the high altar of the twelfthcentury abbey, and Alexander III and Robert I as buried east of them, before the site of the post-1250 high altar. Finally, Bryce accepted and emphasised the unique testimony of the Chronicle of Lanercost, which describes Alexander III as being buried at Dunfermline solus, 'alone', on the pars meridiana, near the presbyterum. ${ }^{92}$ Bryce took solus as further

\footnotetext{
${ }^{87}$ Chron. Fordun, 305; Watt, Scotichronicon, v. 402-3; Steve Boardman, 'Dunfermline as a royal mausoleum', in Fawcett (ed.), Royal Dunfermline, 139-53, at 143.

${ }^{88}$ Richard Fawcett, 'Dunfermline Abbey Church', in Fawcett (ed.), Royal Dunfermline, 27-63, at 51-2. The exceptions for whom there is a formal possibility of burial as part of the second group, Queens Euphemia (d. 1387x88) and Annabella (d. 1401), cannot be identified with the skeleton exhumed in 1819, on grounds of gender.

89 Bryce, 'The Skull of King Robert the Bruce', 81-91; Fraser, 'The tomb of the hero king', 155-76.

${ }^{90}$ F. C. Eeles, 'The Development and Internal Arrangement of the Abbey Church of Dunfermline', in The Burgh Records of Dunfermline, ed. Erskine Beveridge (Edinburgh, 1917), xxxi-xlvii, at xxxviii.

${ }^{91}$ Bryce, 'The Skull of King Robert the Bruce', 85; Fraser, 'The tomb of the hero king', 173

${ }^{92}$ Chron. Lanercost, 117. Presbyterum is presumably an error for presbyterium; ibid., 394.
} 
confirmation that Alexander III was buried east of David I and Malcolm IV, not alongside them: the first burial in front of the post-1250 high altar. He took the rest of Lanercost to mean, 'the pars meridiana [south side] of the choir near the presbytery, which was very probably added when the choir was extended' ${ }^{93}$ Strict acceptance of Bryce's interpretation of the evidence available to him would therefore place Bruce in the vault discovered in 1818, buried 'in the middle of the choir' as stated by Bower, with David I and Malcolm IV to the west and Alexander III to the south. His conclusion, however, declined to push the evidence to the limit: 'there is a probability, even a strong probability, but not a certainty that the tomb discovered in 1818 was actually that of King Robert the Bruce'. ${ }^{94}$

Iain Fraser reaches much the same conclusion while diverging from Bryce at points. He sees ambiguity in Lanercost, suggesting that it could mean that Alexander III's tomb was placed not in the body of the choir, but at 'a location in the south choir arcade'. ${ }^{95}$ Part III supports Bryce on this point. Secondly, Fraser argues that the need to provide ambulatory space to create appropriate access to Margaret’s chapel would have made it impossible to move the high altar eastwards by as much as a bay, or indeed at all. For Fraser, at most the burials of David I and Malcolm IV could have been separated from those of Alexander III and Robert I by 'a matter of yards'; at least they would have formed 'a tighter cluster, in the vicinity of the twelfth-century altar' ${ }^{96}$ Part III supports Fraser on this point, and links it to another potential problem with Bryce’s line of argument, that of mode of burial. Bryce himself was sensitive to this, knowing that evidence existed that Bruce was buried beneath a substantial above-ground tomb. Concerned that this would have obstructed access to the high altar, he surmised that 'a fair marble slab on the floor level, which in no way obstructed the approach to the altar, is a more likely form for a monument in medio chori [in the middle of

\footnotetext{
93 Bryce, 'The Skull of King Robert the Bruce', 86.

${ }^{94}$ Bryce, 'The Skull of King Robert the Bruce', 91.

${ }^{95}$ Fraser, 'The tomb of the hero king', 160.

${ }^{96}$ Ibid.
} 
the choir] to have taken'. ${ }^{97}$ This looks like wishful thinking, and all the more so in the wake of the recent project combining the surviving medieval tomb fragments recovered from Dunfermline with the documentary record to create a virtual reconstruction of the likely form of Bruce's tomb: a marble tomb chest surmounted by an effigy with canopy above. ${ }^{98}$ Moreover, while the dates of death of David I and Malcolm IV and the wording of their death notices in the chronicles both suggest that they may have been buried beneath slabs set flush in the abbey floor, the forms of burial accorded to Margaret Plantagenet, Alexander III and Elizabeth de Burgh are unknown.

We are brought face to face with a conundrum which appears intractable, existing as it does in the shadow of Fernie's sobering observation that given what has been lost at Dunfermline, 'there is no basis for the apparently assured plans which are often published of the eastern arm'. ${ }^{99}$ Bryce and Fraser's discussions can be used to posit a second burial group consisting of six graves, in two rows of three: firstly David I with Malcolm IV to his right and Margaret Plantagenet presumably to his left; ${ }^{100}$ secondly, and to the east, Robert I in the middle of the choir, with Alexander III to his south side and Elizabeth de Burgh presumably on his north side. However, the scheme is open to question on three counts. The challenge of the evidence of Lanercost is that solus, 'alone' seems to insist on space between Alexander III and other burials presumed to lie to his west, while presbyterum, 'presbytery', equally insists on space between his tomb and the high altar to the east. Fraser's concern is the scope for that space to exist: how far, if at all, the twelfth-century high altar was capable of being moved further east as a consequence of the extension to the eastern arm completed by 1250 .

\footnotetext{
${ }^{97}$ Bryce, 'The Skull of King Robert the Bruce', 87.

${ }^{98}$ Fraser, 'The tomb of the hero king', 156-7, 159-60, 170-72. For the virtual reconstruction, which featured in an exhibition at the Hunterian Museum, University of Glasgow, in 2015, see https://www.gla.ac.uk/hunterian/visit/exhibitions/virtualexhibitions/robertthebruce; accessed 4 Feb. 2019. ${ }^{99}$ Eric Fernie, 'The Romanesque Churches of Dunfermline Abbey', in John Higgitt (ed.), Medieval Art and Architecture in the Diocese of St Andrews, The British Archaeological Association (Leeds, 1994), 25-37, at 30. ${ }^{100}$ For discussion of the meaning of 'right' and 'left' in this context, see MacGregor and Wilkinson, 'In Search of Robert Bruce, Part III'.
} 
Finally, there is the presence before the high altar of at least one substantial above-ground tomb. All three issues coalesce into one: the existence of sufficient space before Dunfermline Abbey's high altar to accommodate tombs whose number, size and proximity both to each other and to the altar seem incompatible with the altar's main function, the celebration of the mass and the liturgy.

Michael Penman's radical solution is to relocate the tombs of Bruce and his queen to 'the north aisle of the choir, within ambulatory space leading to St Margaret's feretory shrine' ${ }^{101}$ Part III rejects this on the grounds that it would have impaired visual access to a monument—Bruce’s tomb—-designed to be seen from all directions; that it disregards without explanation the testimony of Barbour and Bower for Bruce's burial in the choir, or middle of the choir; that all the evidence is compatible with the conclusion that the main body of the choir, and the vicinity of the high altar, became the accustomed place of burial of medieval Scottish kings at Dunfermline; and that Bruce is unlikely to have broken with accepted practice, mindful as he ever was of asserting to all, and by every means at his disposal, the legitimacy of his kingship, his relationship to his kingly predecessorsparticularly Alexander III—and the 'royal dignity' of Scotland. Already in November 1314 he had made a grant to Dunfermline propter honorem sepulture regum predecesssorum nostrorum qui ibidem sepeliuntur ac sepulture nostre quam apud ipsos specialiter elegimus: 'for the sake of the honour of the burial place of the kings our predecessors who are buried there, and of our own burial place which we have expressly chosen among them' ${ }^{102}$

On the basis of a close reading of the chronicles, including the unpublished 'Dunfermline Chronicle', the papal evidence and the texts of the life and miracles of Queen Margaret, Part III advances an alternative hypothesis for understanding the phases, both of

${ }^{101}$ Penman, Robert the Bruce, 305-6.

102 RRS v. 332. 
medieval royal burial at Dunfermline, and of the evolution of the church itself. It is argued that David I, and by implication Malcolm IV and Margaret Plantagenet, were buried beside Queen Margaret, her husband Malcolm III and their sons Edward, King Edgar and King Alexander I, as part of the first royal burial group. It is then argued, on separate grounds, that when David's abbey was dedicated in 1150 it did not at this stage incorporate the now lost choir as has been generally assumed, but was superimposed upon and largely co-extensive with the church built by Queen Margaret, which it supplanted. What was built by 1150, which still survives, then became the nave to the abbey choir now lost, which was completed by 1180, the year of Queen Margaret's first translation to a tomb beside the relocated high altar. Contemporaries now referred to the nave as the 'old church', 'former church' or 'outer church', and to the choir as the 'inner church'. The original high altar now became the nave altar. When in 1250 Queen Margaret underwent her second translation from her tomb by the high altar to the tomb in the feretory chapel now added to the choir, the high altar remained in the same or substantially the same position. The two arguments coalesce in that David I must needs have been buried alongside his parents and brothers in 1153, if at this stage the choir now lost was still to be built.

The hypothesis brings no certain resolution to a question which ultimately may only be answerable, if at all, through the application of new technologies to investigate what lies beneath what was Dunfermline Abbey. It is a radical departure from the orthodoxy, and must be regarded as provisional until scrutinised by historians of medieval church architecture. The congestion it resolves in respect of the second burial group becomes instead the problem of the first group, which would swell to eight tombs. However, only five tombs were uncovered in Dunfermline’s nave or 'old church’ by Macgregor Chalmers’s excavation in 1916, a discrepancy difficult to account for. ${ }^{103}$ If it can be accepted, the hypothesis would reduce the

${ }^{103}$ MacGregor and Wilkinson, 'In Search of Robert Bruce, Part III’. 
second burial group to three in number, and quash the need to postulate a shifting of position of the high altar in order to accommodate six burials before it. Alexander III's burial solus, 'alone', would logically refer to his status as the first burial to take place before this high altar. While the mode of burial of Alexander III and Elizabeth de Burgh would remain unknown, it is easier to believe that their tombs, and that of Robert Bruce, could be accommodated in the choir at a sufficient remove from the high altar to avoid compromising access to it, if theirs were the only three tombs located there, as opposed to three of six tombs. By removing David I and Malcolm IV from the second burial group, which would then consist of Bruce's tomb in the middle of the choir, with Alexander III to the south and Elizabeth de Burgh to the north, the hypothesis, if correct, would single out Bruce as the likely occupant of the tomb discovered in 1818, a conclusion also favoured by Bryce and Fraser on the basis of their alternative reading of the evidence. Under either hypothesis, the conclusion drawn here is that the evidence for tomb location cannot allow Bruce's candidature to be ruled out, and that greater violence is done to the evidence by ruling him out than by accepting that he was buried in the choir of Dunfermline Abbey.

Seventh, two contemporaries noted that it was 'in the immediate neighbourhood of the tomb' or 'contiguous to the tomb' that several fragments of dressed marble were recovered as a result of the investigations of 1818-19. ${ }^{104}$ Among these may have been the two fragments noted by Jardine as having been deposited in 'The Museum of the Society of Scottish Antiquaries', forerunner of the modern Museum of Scotland. ${ }^{105}$ The Museum of Scotland holds ten marble fragments from Dunfermline Abbey, and as already noted, it has proved possible to bring these together with six fragments of the same provenance held in Glasgow University's Hunterian Museum, to create a virtual reconstruction of the one tomb to which

\footnotetext{
${ }^{104}$ Fraser, 'The tomb of the hero king', 170-1.

105 [Jardine], Report, 19.
} 
they all apparently belonged. Since this tomb was apparently modelled upon those used in the burial of medieval French royalty at the abbey of St Denis, near Paris, and since Bruce's tomb was obtained from Paris, the possibility is that all the extant Dunfermline fragments belong to the tomb of Robert Bruce. ${ }^{106}$ However, the contemporary evidence is too vague to link any of these fragments with certainty to the tomb opened and investigated in 1818-19. In any case, as the rejected detritus of a tomb long since destroyed, robbed out and dispersed, the point of recovery of these fragments cannot be taken as a reliable index of their point of origin. $^{107}$

Rejection of this last potential benchmark leaves six discussed thus far by which to identify the incumbent of the tomb excavated at Dunfermline in 1818-19: sex, physique, age, leprosy, heart removal and tomb location. The individual was male, ruling out Margaret Plantagenet, Elizabeth de Burgh and any later Scottish queens who may have been buried in Dunfermline's choir. The powerful physique is consistent with the Bruce who slew Henry de Bohun in the manner he did at Bannockburn, ${ }^{108}$ and whose military career far surpassed those of David I, Malcolm IV and Alexander III in intensity and duration. Equally, it gives no grounds for ruling them out, given the expectation of participation in military culture and readiness for combat, along with the dietary privileges, that were concomitant with their social rank. The suggested age range at death of 40 to 65 years fits Bruce (nearly 55) and Alexander III (44), raises a question mark against David I although his exact age at death is not known (late 60s or early 70s?), and counts against Malcolm IV, who died aged $23 .{ }^{109}$ As

\footnotetext{
${ }^{106}$ Fraser, 'The tomb of the hero king', 159-60, 169-74. For the virtual reconstruction see above, n. 98. All the known extant Dunfermline marble fragments are white, but Jardine and another contemporary attest to the existence of black marble fragments ([Jardine], Report, 46; Fraser, 'The tomb of the hero king', 171). Both white and black marble were used in the medieval French royal tombs at St Denis; ibid., 169-70.

${ }^{107}$ Fraser, 'The tomb of the hero king', 173.

108 Barrow, Robert Bruce, 218.

109 Dunbar, Scottish Kings, 64, 73, 98, 140; Richard Oram, David I: The King who made Scotland (Stroud, 2004), 49. Age gives further grounds for excluding Robert duke of Albany, who must have died aged around 80; ER iv. clxxv. A. A. M. Duncan, The Kingship of the Scots, 842-1292: Succession and Independence (Edinburgh, 2002), 73-5, argues on slender grounds that Malcolm IV died of Paget's disease, which involves
} 
argued in Part I, the skull cast exhibits features consistent with a diagnosis of leprosy, while it has been argued here that the evidence of the chronicles which claim that Bruce succumbed to lepra, la lepre or la grosse malade should be allowed. Admitting leprosy as a benchmark, then of those kings to whom the Dunfermline skull cast might have belonged, only Bruce can be positively associated with a condition which could have given rise to the pattern of bone loss the skull cast may exhibit. Alexander III and Robert I are the only two candidates for whom evidence exists of separate heart burial, the evidence being more substantive in Bruce’s case. David I and Malcolm IV cannot be excluded on this score, but recorded Scottish instances of the practice commence significantly later than the mid-twelfth century. Tomb location narrows the possible options to four kings: David I, Malcolm IV, Alexander III and Robert I. It cannot rule out Bruce as a candidate, and offers grounds for favouring him and - if the hypothesis presented in Part III and summarised here is correct—of ruling out David I and Malcolm IV.

Manner of death is a seventh and final relevant benchmark. Alone of the four candidates Alexander III died violently, on the coast road to Kinghorn on the night of 18-19 March 1286. He is said by the chronicle sources, English and Scottish, to have been thrown from his horse — as they may have assumed given that they say he died alone — and to have broken his neck, as they may have known more certainly. ${ }^{110}$ It might be expected that his skeleton would exhibit trauma consonant with the manner of his death. Having commented on the skull investigated in 1819, Jardine’s report continues:

the other bones of the skeleton ... we found in a perfect state, in their natural position; one of the vertebrae only being separated from the corresponding one about the

\footnotetext{
enlargement and deformation of the bones, particularly the tibia and skull, characteristics not present in the Dunfermline skeleton.

${ }^{110}$ Chron. Lanercost, 117; Chron. Hemingburgh, 30; Watt, Scotichronicon, v. 420-1; Dunbar, Scottish Kings, 98.
} 
distance of an inch. The whole were minutely examined, and found in an entire and perfect state’. 111

Bryce treated this statement seriously because 'the close wrapping of the body in two sheets of lead seems to have retained the parts of the skeleton very closely in their natural positions', but adds: 'we are not told in what region of the spine this dislocated vertebra occurred ... had [it] occurred in the cervical region of the spine it might have been decisive in favour of Alexander' ${ }^{112}$ The plate depicting the skeleton in the official report shows no separation of vertebrae in what it shows of the spine, either in the lower section up as far as the sternum, or in the neck. The separation may therefore have been present in the intermediate section, but there is also the possibility that the illustrator simply eliminated the gap. However, according to the Perthshire Courier's account of proceedings at Dunfermline on 5 November 1819, the skull had to be 'disjoined from the body, and held up to the admiring gaze of the spectators'. ${ }^{113}$ This accords with the illustration of the skeleton in situ in the tomb, included by Jardine not in the official report but in extracts from it published separately. Here the neck vertebrae are clearly intact and connected both to each other and to the skull, which would thus need to have been disjoined in order to be held aloft. ${ }^{114}$

Bryce, a professor of anatomy, evidently saw the absence of trauma elsewhere in the skeleton as no grounds for excluding an identification with Alexander III. What Bryce was disposed to hold against him was the modest height of the individual whose skeleton this was, given that the word portrait in Bower's Scotichronicon describes Alexander as procerus or

\footnotetext{
111 [Jardine], Report, 36-7.

112 Bryce, 'The Skull of King Robert the Bruce', 90.

113 The Perthshire Courier, 18 Nov. 1819.

${ }^{114}$ Henry Jardine, 'Extracts from the Report made by Henry Jardine, Esquire, His Majesty’s Remembrancer in Exchequer, relative to the Tomb of King Robert Bruce, and the Church of Dunfermline', Archaeologica Scotica: or Transactions of the Society of the Antiquaries of Scotland 2 (1822), 435-55, Plate XIV (facing 441).
} 
distinctively tall in stature. ${ }^{115}$ Bower's later date of composition may make his testimony on this score less reliable that in that of the layout of the Dunfermline royal tombs. The presence of a cervical dislocation in the skeleton of the occupant of the Dunfermline tomb would indeed be dramatic and potentially decisive evidence in favour of Alexander III, but three sources - the illustration in the official report, the illustration accompanying the extracts from the official report as separately published, and the report in the Perthshire Courier —all suggest no dislocation of the neck.

As already noted, in 1926 Bryce concluded that: 'there is a probability, even a strong probability, but not a certainty that the tomb discovered in 1818 was actually that of King Robert the Bruce'. ${ }^{116}$ We conclude that this remains a defensible position, and that the greater number of benchmarks investigated here increases the strength of that probability. The fuller evidence available for Bruce allows him alone to be tested against seven relevant benchmarks, which individually and collectively yield no substantive grounds for ruling him out, and give substantive grounds for favouring him over others, even if they cannot put the matter beyond doubt. Given that fresh documentary evidence of the requisite sort is now unlikely to surface, the best hope of further progress lies in science, and analysis both of what lies below ground at the site of the medieval abbey, and of artefacts—notably cloth, coffin wood and bone-with a demonstrable provenance that connects them to the tomb discovered and investigated at Dunfermline in 1818-19. ${ }^{117}$

\footnotetext{
115 Ibid., 89-90; Watt, Scotichronicon, v. 420-1.

${ }^{116}$ Bryce, 'The Skull of King Robert the Bruce', 91.

${ }^{117}$ For one of the six iron rings or handles affixed to the larger of the two slabs which covered the Dunfermline vault, and now in the Hunterian Museum, see [Jardine], Report, 28-9, and https://www.gla.ac.uk/hunterian/visit/exhibitions/virtualexhibitions/robertthebruce/ (last accessed 4 Feb. 2019). For cloth fragments held in the Hunterian Museum and Museum of Scotland, see above, n. 22, and Fraser, 'The tomb of the hero king', 168. For a summary survey of evidence for survival of 'relics' from the Dunfermline investigations of 1818-19, see Penman, 'Robert Bruce’s Bones, 64, n. 112, to which can be added two bone fragments held by Dumfries Museum: http://www.futuremuseum.co.uk/collections/people/key-people/nationalheroes/robert-(i)-the-bruce/robert-the-bruce,-top-of-his-femur-and-section-of-his-foot.aspx (last accessed 4 Feb. 2019). The letter of 1820 apparently written by James Gregory refers to a metatarsal bone removed from Dunfermline on 5 November 1819 and placed 'in a glass phial, with a ground-glass stopper, and an explicit memorandum telling whose bone it is, and when it was stolen' ([ ' $G$ '], 'Exhumation and Re-interment of Robert
} 
$19 / 02 / 19$

15:51

8518 words; 12060 words plus footnotes

Bruce', 142). An artefact whose label claims it contains fragments of metatarsal bone and coffin wood recovered from Dunfermline Abbey on 5 November 1819 is currently under investigation by the universities of Glasgow and Leicester. 